\title{
Inhibitors of Phosphodiesterase Isoforms III or IV Suppress Islet-Cell Nitric Oxide Production
}

\author{
Evette Beshay and Gérald J. Prud'homme \\ Department of Pathology, McGill University, Montreal, Quebec, Canada
}

\begin{abstract}
SUMMARY: The general phosphodiesterase (PDE) inhibitor pentoxifylline (PTX), and the PDE type IV inhibitor rolipram (ROL), both increase intracellular cAMP levels and suppress inflammatory cytokine production by $T$ cells and macrophages. We have previously shown that PTX and ROL protect from autoimmune diabetes in nonobese diabetic (NOD) mice. These drugs may mediate some of their anti-inflammatory effects by blocking nitric oxide (NO) production by macrophages. In this study, we investigated the effect of PDE inhibitors in blocking NO production by insulin-secreting NIT-1 insulinoma cells and mouse islet cells in vitro and in vivo. Insulinoma cells and islet cells produced NO when stimulated with a combination of inflammatory cytokines and lipopolysaccharide (LPS). We found that both PTX and ROL markedly suppressed this induced NO production. Islet cells express PDEs III and IV and, accordingly, the PDE III inhibitor cilostamide (CIL) also suppressed NO production, and a combination of ROL and CIL had a synergistic effect. This suppression appeared to be mediated, at least in part, by elevating CAMP level and was mimicked by other cAMP-elevating agents, ie, membrane-permeable cAMP analogs (dibutyryl cAMP and 8-bromo cAMP) and an adenylate cyclase stimulator (forskolin). PDE inhibitors suppressed the expression of inducible nitric oxide synthase (iNOS) mRNA. In vivo treatment with PTX or ROL prevented iNOS protein expression in the islets of NOD mice with cyclophosphamide-accelerated disease. Our findings suggest that PDE inhibitors can protect islets against autoimmunity. (Lab Invest 2001, 81:1109-1117).
\end{abstract}

$T$ he isozymes of cyclic-3',5' nucleotide phosphodiesterase (PDE) are critically important components of the cyclic-3',5' adenosine monophosphate (CAMP) protein kinase A (PKA) signaling pathway. PDE inhibitors elevate intracellular CAMP levels and can regulate many processes, including immune responses. There are at least 10 PDE families (Bielekova et al, 2000), several subtypes, and numerous isoform splice variants. PDE isozymes differ in molecular structure, catalytic properties, intracellular regulation and location, sensitivity to selective inhibitors, and selective expression in various cell types.

PDE type IV (PDE4) is the major type in macrophages, whereas lymphocytes express both type III (PDE3) and PDE4 (Schudt et al, 1995). Islet $\beta$ cells, like lymphocytes, have been shown to express these two types (Parker et al, 1995). Rolipram (ROL), a specific PDE4 inhibitor, and pentoxifylline (PTX), a general PDE inhibitor, suppress inflammatory cytokine production and are therapeutically effective in several autoimmune and/or inflammatory diseases. For example, ROL (Sommer et al, 1995) and PTX (Rott et al, 1993) prevent experimental allergic en-

Received April 11, 2001.

This study was funded by the Canadian Diabetes Association. EB is supported by a fellowship of the Royal Victoria Hospital Research Institute, Montreal, Qc, Canada.

Address reprint requests to: Dr. Gérald J. Prud'homme, 3775 University St., Room B13, Montreal, Qc, Canada H3A 2B4. E-mail: gprudh@po-box.mcgill.ca cephalomyelitis in rodents, and PTX has been found to inhibit contact dermatitis in mice (Schwarz et al, 1993). Suppression of TNF $\alpha$ production by these drugs is well documented (Badger et al, 1994; Liang et al, 1998). We have shown that ROL and PTX prevent insulitis, spontaneous diabetes, and cyclophosphamide (CYP)-accelerated diabetes in nonobese diabetic (NOD) mice (Liang et al, 1998). In addition, we showed that these drugs suppress interferon $\gamma \quad(\mathrm{IFN} \gamma)$ and interleukin-12 (IL-12) production.

Cytokines appear to be important mediators of islet $\beta$-cell dysfunction and destruction. Interleukin $1 \beta$ (IL-1 $\beta$ ), IFN $\gamma$, and TNF $\alpha$, particularly in combination, are toxic to $\beta$ cells in culture (Bergmann et al, 1992; Rabinovitch and Suarez-Pinzon, 1998). The molecular mechanisms of toxicity are not well understood. However, cytokines augment inducible nitric oxide synthase (iNOS) expression and consequently nitric oxide (NO) production, and some investigators have proposed that this contributes to islet cell damage (Corbett et al, 1993).

We recently reported that $\mathrm{ROL}$ and PTX suppress NO production by macrophages in vitro and in vivo (Beshay et al, 2001). However, the effects of these PDE inhibitors on NO production by islet cells have not been extensively studied. In this study, we demonstrate that PDE3 or PDE4 inhibitors block NO production by islet cells, and the combined inhibition is most effective. This inhibitory effect is apparent in vivo and provides an important new avenue for the prevention or treatment of inflammatory/ autoimmune diseases. 


\section{Results}

\section{PTX, ROL, and Cilostamide Inhibit NO Production by NIT-1 Cells and Islet Cells}

$\mathrm{NO}$ is rapidly transformed to nitrite in culture (breakdown stable product), and we measured nitrite levels as an indication of NO production. In the absence of stimulation, NIT-1 cells produced an undetectable amount of nitrite (not shown). When IL-1 $\beta$ was added alone, a small amount of nitrite was detected, but when either IFN $\gamma, \operatorname{TNF} \alpha$, or lipopolysaccharide (LPS) was added alone, nitrite was undetectable (not shown). However, NIT-1 cells produced a considerable amount of NO when stimulated with a combination of IL-1 $\beta(5 \mathrm{ng} / \mathrm{ml}), \operatorname{TNF} \alpha(10 \mathrm{ng} / \mathrm{ml}), \operatorname{IFN} \gamma(0.4$ $\mathrm{ng} / \mathrm{ml}$ ), and LPS (30 ng/ml) (Fig. 1, A to C). Although, this has not been reported before, LPS had a stimulatory effect. This cytokine combination and these concentrations were found optimal in preliminary experiments and were used subsequently.

We found that ROL suppresses nitrite production in a dose-dependent manner (Fig. 1A). A concentration of $6.25 \mu \mathrm{M}$ ROL was sufficient to significantly suppress nitrite production $(p=0.009)$, whereas a $200 \mu \mathrm{M}$

A

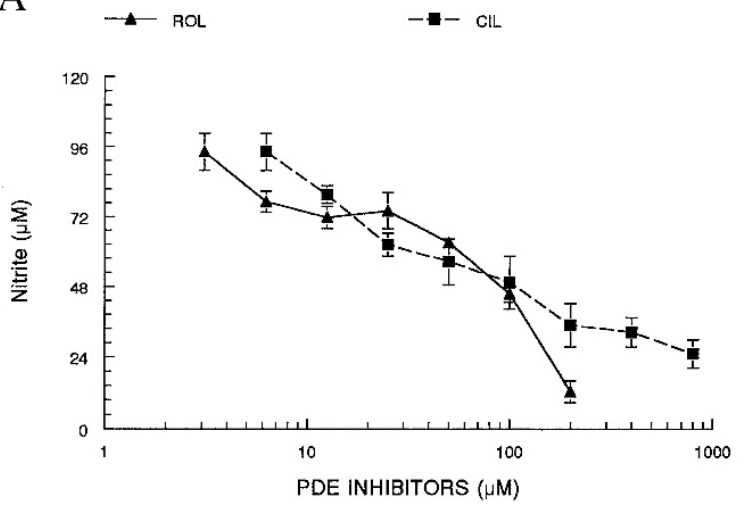

concentration suppressed $87 \%$ of nitrite production. PTX also suppressed nitrite production but at a higher concentration (ROL IC $\mathrm{IC}_{50}=96.5 \mu \mathrm{M}$ and $\mathrm{PTX} \mathrm{IC} \mathrm{IC}_{50}=$ $1.48 \mathrm{~mm}$ ) (Fig. 1B). Thus, on a molar basis, ROL was 15 times more potent than PTX. The suppression of NO production cannot be attributed to cell death induced by PDE inhibitors because there was no increase in dead cells as determined by Trypan blue dye exclusion, and no decrease in adherent-cell DNA content, but, on the contrary, survival was moderately increased (data not shown).

Cilostamide (CIL), a specific PDE3 inhibitor, also suppressed NO production $\left(\mathrm{IC}_{50}=327.5 \mu \mathrm{M}\right)$ (Fig. 1A). Notably, a combination of ROL and $\mathrm{CIL}$ has a strong suppressive effect on NO production (Fig. 1C), much higher than either drug alone. Thus, ROL at $12.5 \mu \mathrm{m}+$ CIL at $12.5 \mu \mathrm{M}$ markedly inhibited NO production, but not $25 \mu \mathrm{m}$ of each inhibitor alone. This was greater than a simple additive effect, suggesting a synergistic effect.

Mouse islet cells also produced NO when stimulated with the same cytokine/LPS mixture as with NIT-1 cells and, similarly to insulinoma cells, ROL and PTX suppressed NO production ( $p<0.001$ ) (Fig. 2).
B

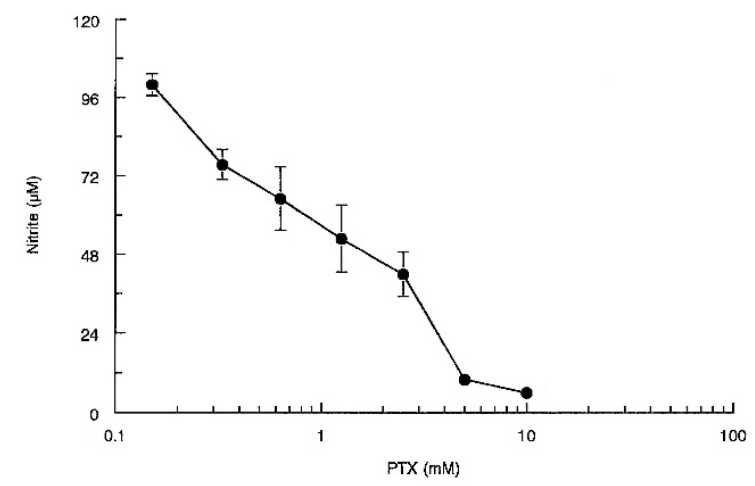

C

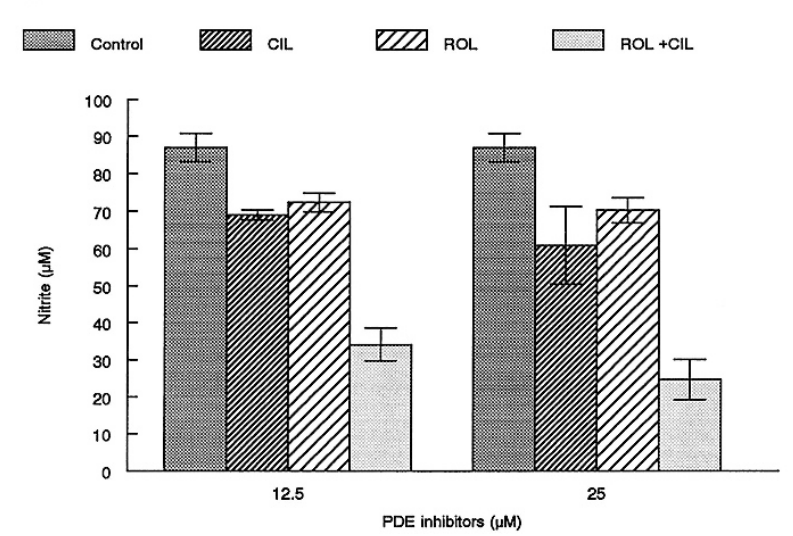

Figure 1.

Suppression of nitric oxide (NO) production by phosphodiesterase (PDE) inhibitors. NO production from interleukin- $1 \beta$ (IL-l $\beta)(5 \mathrm{ng} / \mathrm{ml})$, tumor necrosis factor- $\alpha$ $($ TNF $\alpha)(10 \mathrm{ng} / \mathrm{ml})$, interferon- $\gamma($ IFN $\gamma)(0.4 \mathrm{ng} / \mathrm{ml})$, and lipopolysaccharide (LPS) $(30 \mathrm{ng} / \mathrm{ml})$ - costimulated NIT-1 insulinoma cells was determined by measuring nitrite levels (a stable product derived from NO) using the Griess reagent, in 40-hour culture supernatants. A, Suppression of NO production by rolipram (ROL) and cilostamide (CIL). B, Suppression of NO production by pentoxifylline (PTX). C, CIL and ROL combination. The results represent the mean of triplicate cultures \pm 1 SD. A representative experiment is shown for each drug or combination, and three independent experiments yielded similar results in each case. 


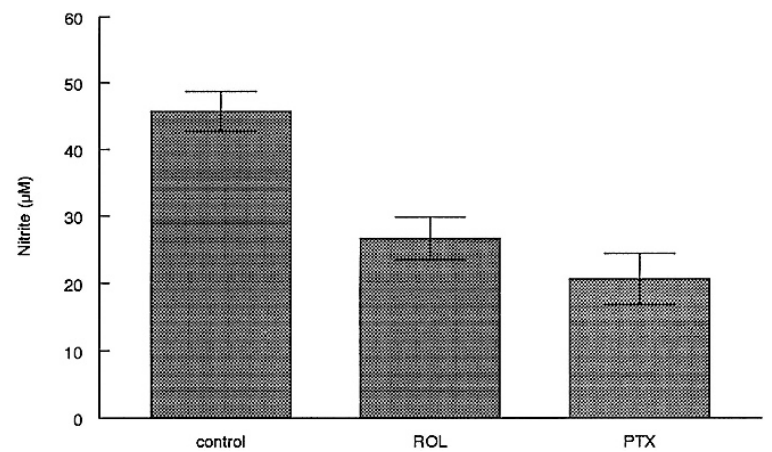

Figure 2.

Suppression of NO production in mouse islet cells by PDE inhibitors. NO production from IL-1 $\beta(5 \mathrm{ng} / \mathrm{ml})$, TNF $\alpha(10 \mathrm{ng} / \mathrm{ml})$, IFN $\gamma(0.4 \mathrm{ng} / \mathrm{ml})$, and LPS $(30 \mathrm{ng} / \mathrm{ml})-$ costimulated mice islets are reported. ROL $(200 \mu \mathrm{M})$ or PTX (5 $\mathrm{mm}$ ) significantly suppressed NO production $(p<0.01)$. The results represent the mean of triplicate cultures $\pm 1 \mathrm{sD}$. A representative experiment is shown and three independent experiments yielded similar results.

Macrophages constituted less than one cell per 2000 islet cells as determined by flow cytometry analysis with Mac-1 antibody staining and ingestion of fluorescent microbeads in culture (data not shown). We found that the amount of nitrite produced by this number of peritoneal macrophages was less than $2 \mu \mathrm{M}$ (not shown), which is much less than the values produced by islet-derived cells. Thus, NO does not appear to be produced by contaminating macrophages.

\section{ROL and PTX Block iNOS mRNA Expression}

We analyzed the expression of iNOS mRNA at different time points, in stimulated (IL-1 $\beta, \mathrm{TNF}-\alpha$, IFN- $\gamma$, and LPS) NIT-1 cells, in the presence or absence of ROL or PTX. iNOS mRNA expression was maximal after 4 hours and severely inhibited by either ROL (200 $\mu \mathrm{M})$ or PTX (5 mM) (Fig. 3), as determined by semiquantitative reverse transcription-polymerase chain reaction (RT-PCR) analysis.

\section{cAMP Elevating Factors Inhibit NO Production by NIT-1 Cells}

Membrane-permeable cAMP analogs, dibutyryl cAMP and 8-bromo-cAMP, both inhibited NO production by stimulated NIT-1 cells (Fig. 4A). Similarly, forskolin, which elevates cAMP levels by stimulating adenylate cyclase, suppressed NO production by NIT-1 cells (Fig. 4B). Cell death was not increased by these agents (not shown).

\section{ROL or PTX Treatment Inhibits iNOS Expression in Pancreatic Islets}

Ten days after receiving a dose of $250 \mathrm{mg} / \mathrm{kg}$ of CYP, most islets of control NOD mice showed insulitis between grade 3 and 4 with many iNOS-positive cells (Table 1). Even the few remaining islets with low-grade insulitis had visible iNOS-positive cells (Fig. 5, A and $B)$, although these cells were clearly found in higher numbers in islets with higher-grade lesions, such as

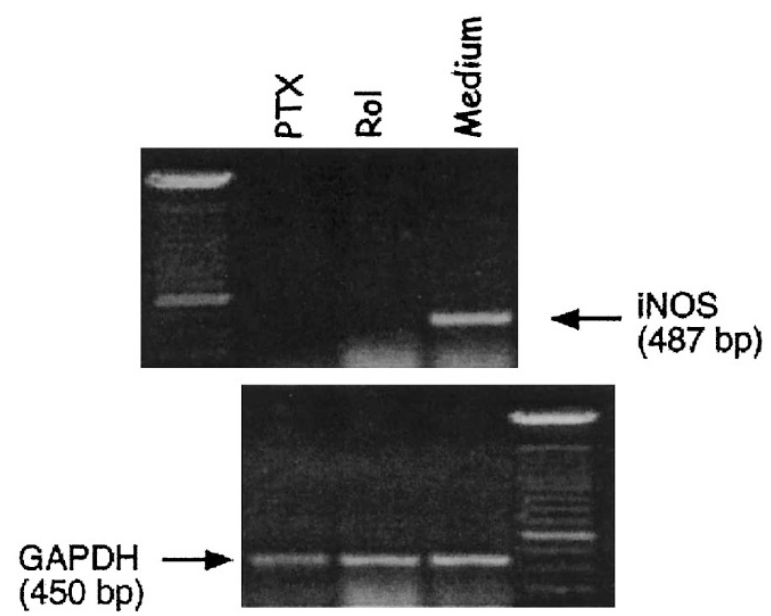

Figure 3.

ROL and PTX suppress inducible nitric oxide synthase (iNOS) mRNA expression. NIT-1 insulinoma cells were stimulated as described in the legend to Figure 1, with either medium alone, ROL $(200 \mu \mathrm{M})$, or PTX (5 mM). Reverse transcription-polymerase chain reaction (RT-PCR) with glyceraldehyde-3phosphate dehydrogenase (GAPDH) and iNOS primers was performed on total RNA extracted at 4 hours after initiation of culture. Agarose gels were stained with ethidium bromide. Upper panel, iNOS RT-PCR; lower panel, GAPDH RT-PCR; DNA 100 bp ladder, left lane of upper panel and right lane of lower panel. A representative experiment is shown and three independent experiments yielded similar results.

grade 3 (Fig. 5C). Most of the iNOS-positive cells appeared morphologically to be endocrine islet cells and were present in some islets with little or no inflammation. However, in inflamed islets, positive cells probably also included macrophages. In groups receiving either $\mathrm{ROL}$ (14 mg/kg, ip, bid) (Table 1, Fig. 5, D to F) or PTX (80 mg/kg, ip, bid) (Table 1, Fig. 5, G and $\mathrm{H}$ ) for 10 days, the severity of insulitis was significantly reduced. In addition, both ROL and PTX reduced the number of iNOS-positive cells $(p<$ 0.0001 ) (Table 1, Fig. 5, F and H). Occasional islets of PDE inhibitor-treated mice showed grade 3 lesions, but even these islets expressed very few iNOSpositive cells (data not shown).

\section{Discussion}

$\mathrm{NO}$ is a potent and pleiotropic mediator with physiologic and toxic activity. NO is synthesized by various isoforms of nitric oxide synthase (NOS) that catalyze the oxidation of $L$-arginine to form $L$-citrulline and $\mathrm{NO}$ (Munzel et al, 1997). NOS exists in constitutive isoforms present in endothelial cells (eNOS) or neurons (nNOS) and in a cytokine or endotoxin-inducible form (iNOS) (Lowenstein et al, 1994; Moncada et al 1991). The iNOS isoform was first identified in macrophages but now has been found in many cells, including hepatocytes, islets cells, chondrocytes, smooth muscle cells, megakaryocytes, thyrocytes, and mesangial cells (Eizirik et al, 1996; Förstermann and Kleinert, 1995; Nussler et al, 1992). NO inactivates important enzymes in $\beta$ cells by nitrosylation of target iron sulfur proteins, eg, mitochondrial aconitase, required for glucose oxidation and insulin release (Corbett et al, 1991; Stadler et al, 1991). This inactivation impairs 
A

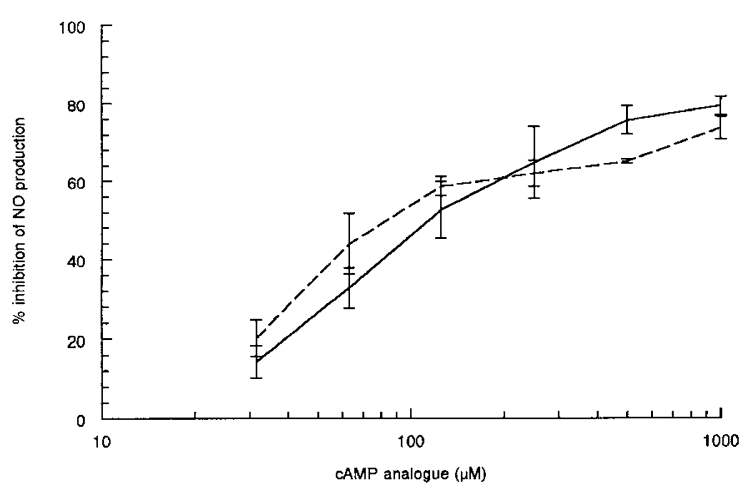

B

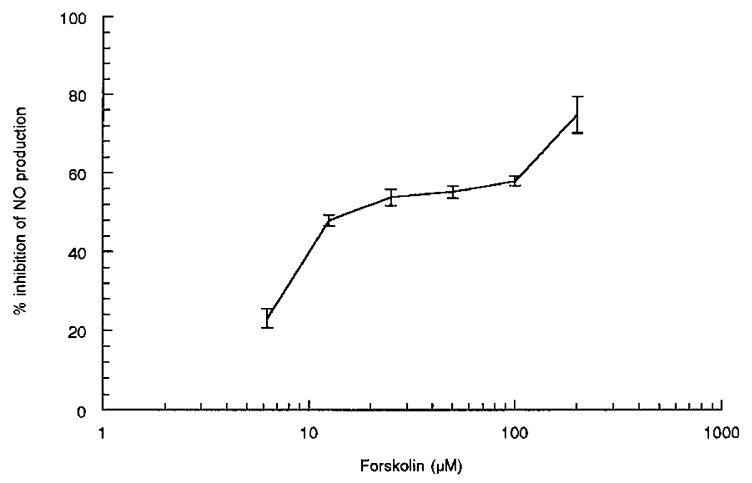

Figure 4.

Agents that increase intracellular cyclic-3',5' adenosine monophosphate (CAMP) levels suppress NO production. The results represent the percent of inhibition of nitrite production by NIT-1 insulinoma cells stimulated as described in the legend to Figure 1. A, CAMP analogs, dibutyryl cAMP (solid line) or 8-bromo-cAMP (broken line). B, Adenylate cyclase stimulator (forskolin). Data represent percent inhibition of nitrite production \pm 1 SD of triplicate cultures in a representative experiment, and three experiments yielded similar results (Panels $A$ and $B$ ).

Table 1. Reduction of iNOS-Positive Islet Cells in CYP-Treated NOD Mice

\begin{tabular}{|c|c|c|c|c|}
\hline \multicolumn{3}{|c|}{ Treatment groups ${ }^{a}$} & \multirow{2}{*}{$\begin{array}{l}\text { Mean grade of } \\
\text { insulitis }^{b}\end{array}$} & \multirow{2}{*}{$\begin{array}{l}\text { iNOS-positive } \\
\text { cells/islet }^{b}\end{array}$} \\
\hline CYP & $\mathrm{ROL}$ & PTX & & \\
\hline+ & - & - & 3.4 & 7.8 \\
\hline+ & - & + & $1.3^{c}$ & $0.5^{c}$ \\
\hline+ & + & - & $1.4^{c}$ & $0.6^{c}$ \\
\hline
\end{tabular}

iNOS, inducible nitric oxide synthase; CYP, cyclophosphamide; NOD, nonobese diabetic; ROL, rolipram; PTX, pentoxifylline; H\&E, hematoxylin and eosin.

${ }^{a}$ Female NOD mice (5-6 wk) were injected with CYP $(250 \mathrm{mg} / \mathrm{kg})$. The mice were treated with either PTX $(80 \mathrm{mg} / \mathrm{kg})$, ROL $(14 \mathrm{mg} / \mathrm{kg})$, or PBS, ip, bid, for 10 days ( $n=10$ mice/group). The mice were killed after 10 days of treatment for examination of tissues.

${ }^{b} \mathrm{H} \& \mathrm{E}-\mathrm{stained}$ slides were used for the grading of insulitis. Immunohistochemical identification of iNOS-positive cells was performed on formalin-fixed tissue with a Histo-Mouse SP kit, using a polyclonal rabbit anti-mouse iNOS primary antibody. The results represent the mean number of iNOS-positive cells per islet of Langerhans.

${ }^{c} p<0.001$ ( $\chi^{2}$ test) vs control mice not receiving ROL or PTX.

$\beta$-cell metabolism, diminishes the capacity of insulin secretion, and may eventually cause $\beta$-cell death. NO is likely to be produced by islet-infiltrating macrophages, and such infiltration is an early event in insulitis and essential for the development of diabetes (Lee et al, 1988). However, islet $\beta$ cells could be another source for $\mathrm{NO}$ production, which contributes to $\beta$-cell damage and death.

Agents that elevate cAMP have been reported to inhibit NO production by some cells. We have recently reported (Beshay et al, 2001) that both ROL and PTX suppress iNOS expression and NO production by the RAW 264.7 macrophage cell line and freshly isolated peritoneal macrophages. Bulut et al (1993) found that a combination of prostaglandin E2 (adenylate cyclase activator) and isobutyl methyl-xanthine (IBMX; a general PDE inhibitor) induced prolonged elevation of cAMP level and suppressed iNOS activity in an IFN $\gamma$ / LPS costimulated murine macrophage cell line (J774). Other studies showed that elevated cAMP levels have a cell-type-specific effect on NO production (Lauterbach et al, 1995; Trajkovic et al, 1997).

Some studies have reported that elevating cAMP by IBMX suppresses NO production by rat islet cells stimulated with IL-1 $\beta$ (Andersen et al, 1996). Other studies reported that forskolin inhibited the expression of iNOS by cytokines in rat insulinoma cells (RIN5F) and rat or human islet cells (Belin et al, 1999; Messmer and Brune, 1994). Our study is the first to investigate the effect of specific PDE inhibitors and to report in vivo iNOS suppression in islets of Langerhans.

We observed that cytokine stimulation (IL-1 $\beta$, IFN $\gamma$, and $\operatorname{TNF} \alpha$ ), combined with LPS stimulation, induced NO production by murine NIT-1 insulinoma cells or normal islet cells. We found that PDE inhibitors, such as the general inhibitor PTX, suppressed NO production in both cell types. Islets of Langerhans were isolated from the pancreas of normal CD-1-strain mice, and NO appeared to be produced by endocrine islet cells, rather than contaminating macrophages. Macrophages constituted less than one cell per 2000 islet cells, and the amount of NO (measured as nitrite) produced by equivalent numbers of macrophages was found to be much less than the values obtained with cultured islets.

Therapeutically, it may be desirable to administer an isoform-specific PDE inhibitor rather than a general inhibitor like PTX. Because islet cells express both PDE3 and PDE4 (Parker et al, 1995), it was of interest to compare the effectiveness of selective inhibitors of these enzymes. For this purpose, we inhibited PDE3 with CIL and PDE4 with ROL. We observed that both PDE inhibitors were effective at suppressing NO production when used alone, and several times more effective than PTX on a molar basis. Moreover, when used together they had more than an additive effect, suggesting synergism. Clearly, this is of clinical interest, because potential adverse effects may be reduced by administering these drugs in combination at a reduced dose of each. 

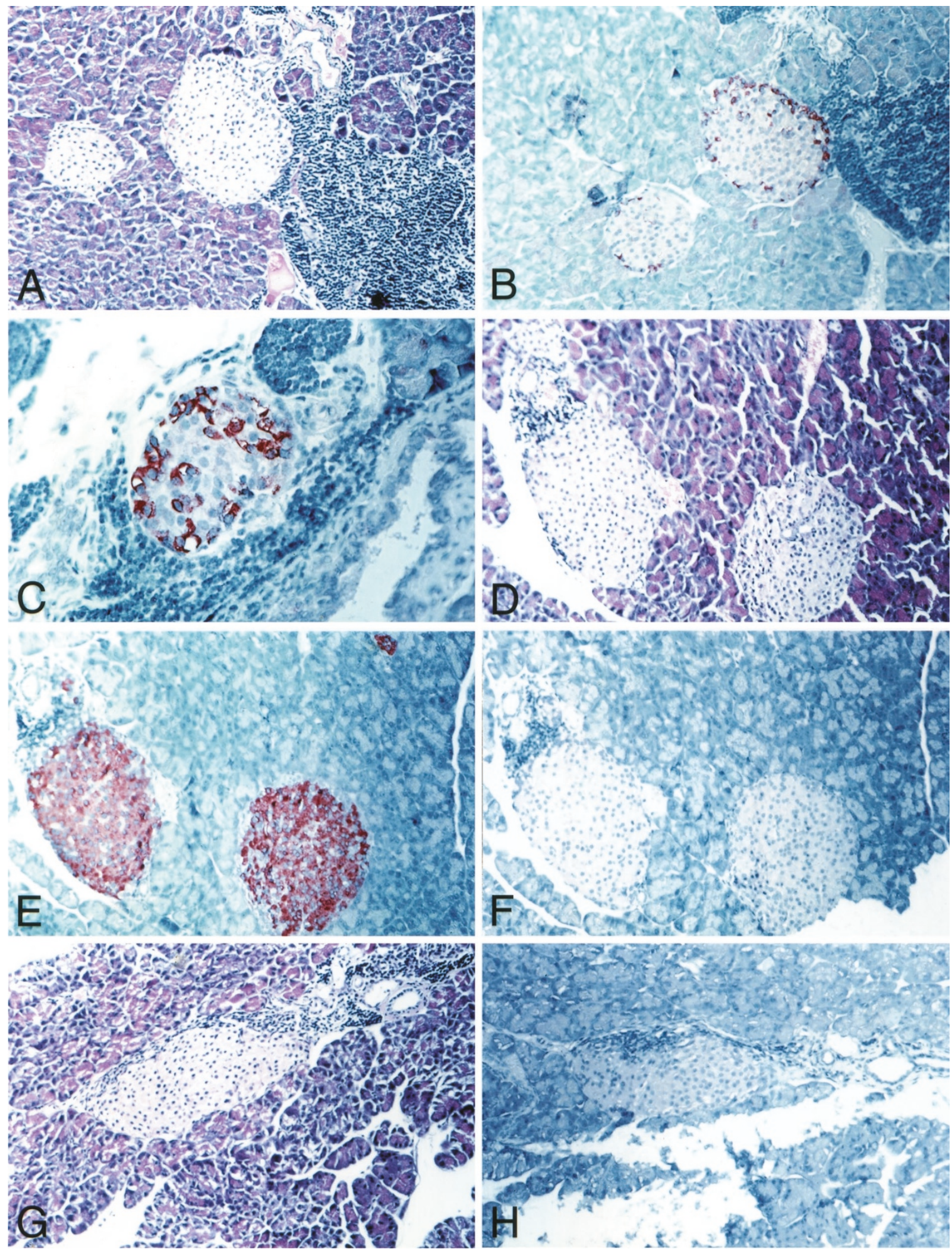

Figure 5.

Immunohistochemical analysis of iNOS expression. Female nonobese diabetic (NOD) mice (5-6 wk) were injected with cyclophosphamide (CYP) (250 mg/kg). The mice were treated with either PTX $(80 \mathrm{mg} / \mathrm{kg}), \mathrm{ROL}(14 \mathrm{mg} / \mathrm{kg})$, or PBS, ip, bid, for 10 days $(n=10$ mice/group), and then killed for examination of tissues. Hematoxylin and eosin (H\&E)-stained slides were used for the grading of insulitis. Immunohistochemical staining for iNOS or insulin was performed in formalin-fixed tissue with the Histo-Mouse SP kit. The primary antibodies were either polyclonal rabbit anti-mouse iNOS or guinea pig anti-human insulin polyclonal antibodies that cross-react with mouse insulin. A, H\&E staining, control CYP-treated mice (no PDE inhibitors). B and C, iNOS staining, control CYP-treated mice. D, H\&E, CYP- and ROL-treated mice. E, Insulin staining, CYP- and ROL-treated mice. F, iNOS staining, CYP- and ROL-treated mice. G, H\&E, CYP- and PTX-treated mice. H, iNOS staining, CYP- and PTX-treated mice. 
The suppression of NO production appeared to be at least partly mediated by elevated cAMP. It was mimicked by raising the intracellular cAMP level by either cell-membrane-permeable cAMP analogs (dibutyrylcAMP and 8-bromo-cAMP) or an adenylate cyclase activator (forskolin). This suppression was at the transcriptional level, because iNOS mRNA expression was markedly inhibited by either PTX or ROL. The mechanism by which the elevation of cAMP inhibits iNOS gene transcription, and ultimately NO production, is yet unclear. In some cells, increased cAMP is associated with reduced activation of nuclear transcription factor $\kappa \beta$ $(\mathrm{NF}-\kappa \beta)$, a transcription factor regulating iNOS gene transcription (Pahana et al, 1997). Interestingly, some cytokines whose production is inhibited by ROL and PTX also have NF- $\kappa \beta$-binding elements in their promoters or enhancers (Heitbrock et al, 1993). We speculate that this could represent a common factor leading to inhibited expression of these genes.

NOD mice develop a form of autoimmune, insulindependent diabetes mellitus (IDDM) similar to the human disease (Rabinovitch and Suarez-Pinzon,1998; Serreze and Leiter, 1994). The precise mechanisms of islet $\beta$-cell destruction in these mice are not totally elucidated, but there is evidence for a T-helper type 1 (Th1)-mediated response with IFN $\gamma$ production, associated with macrophage stimulation and production of IL-12, TNF $\alpha$, IL-1, and NO. In NOD mice, ROL and PTX prevent diabetes, perhaps in part by suppressing $\operatorname{TNF} \alpha$, IFN $\gamma$, and IL-12, as we have shown (Liang et al, 1998), but prior to this study their effect on NO production was not known.

To determine whether PDE inhibitors alter NO production in vivo, we administered these drugs to CYPtreated NOD mice. CYP precipitates the onset of diabetes in these mice and this is associated with increased intra-islet IFN $\gamma$ production (Prud'homme and Chang, 1999). We found that the NOD mice injected with CYP (250 $\mathrm{mg} / \mathrm{kg})$ developed severe insulitis within 10 days of CYP injection and, unlike control mice, had many iNOS-positive islet cells. Most of the iNOS-positive cells had the morphology of endocrine islet cells and were also noted in islets with little or no inflammation. However, in inflamed islets some positive cells were probably macrophages. ROL or PTX treatment markedly reduced the severity of insulitis, as well as the number of iNOS-positive cells in the islets. Thus, from this and previous studies, we now have evidence that PDE inhibitors block at least four mediators (TNF $\alpha$, IFN $\gamma$, IL-12, and NO) that have been implicated in islet-cell destruction.

Clearly, the ability of PDE inhibitors to protect islets from autoimmunity may be related to the suppression of several inflammatory mediators and not necessarily NO. Moreover, in vivo, decreased iNOS expression may have been secondary to decreased cytokine production rather than a direct inhibitory drug effect on the transcription of the iNOS gene. In fact, we observed that the great majority of islets in PDEtreated NOD mice had only low-grade inflammatory lesions. Nevertheless, occasional islets had highergrade (grade 3) lesions but still very few iNOS-positive cells, perhaps reflecting noncytokine-related inhibitory effects.

In terms of the pathogenesis of this disease, there is substantial published evidence that NO can contribute to $\beta$-cell injury. For instance, incubation of rat islets with IL-1 $\beta$ results in a concentration- and timedependent inhibition of glucose-stimulated insulin secretion, followed by cell death after prolonged exposure (Mandrup-Poulsen, 1996). The free radical NO appears implicated, inasmuch as $\beta$-cell damage can be prevented by the NOS inhibitors $N^{G}$-nitro-Larginine methylester (L-NAME) and $\mathrm{N}^{\mathrm{G}}$-monomethylL-arginine (L-NMMA) (Corbett et al, 1993; Corbett and McDaniel, 1995; Southern et al, 1990). We did not systematically examine cell death related to $\mathrm{NO}$ in our cultures, but based on Trypan blue dye exclusion, cell survival was greater in cultures containing PDE inhibitors. A recent study in iNOS gene-knockout mice suggests cytokine-induced islet cell apoptosis is NO independent, whereas necrosis required $\mathrm{NO}$ formation (Liu et al, 2000). Consistent with this, iNOS-deficient mice have increased resistance to streptozotocininduced diabetes (Flodstrom et al, 1999).

We show that PDE inhibitors have a therapeutic potential against NO- and/or cytokine-mediated immunological disorders. Conveniently, these drugs can be administered orally. PTX (Trental; Hoechst, Frankfurt, Germany) is in clinical use for the treatment of intermittent claudication and is well tolerated. ROL has been studied as an antidepressant drug, with side effects including gastrointestinal disorders, dizziness, and headache. Interestingly, a number of newer PDE4 inhibitors have been synthesized, displaying up to 1000 times more affinity for PDE4 than ROL, and perhaps they will have therapeutic advantages. In addition, there are several PDE3 inhibitors available for clinical use, such as cilostamide, cilostazol, milrinone, and amrinone. Cilostazol, for instance, was shown to have minimal side effects and was recently approved for the treatment of intermittent claudication (Cone et al, 1999), because of its vasodilatory and platelet activation inhibitory activities. PDE inhibitors may present a novel therapeutic approach for the treatment of diabetes and other autoimmune and/or inflammatory diseases.

\section{Materials and Methods}

\section{Mice}

Female NOD mice (5-6 weeks) were purchased from Taconic Farms, Inc. (Germantown, New York). Male CD-1 mice (5-6 weeks) were purchased from Charles River Canada (St. Constant, Quebec, Canada). Mice were housed under pathogen-free conditions.

\section{NIT-1 Cell Culture and Stimulation}

The NIT-1 insulinoma cell line is of transgenic NOD mouse origin (ATCC, Rockville, Maryland). To stimulate NO production, NIT-1 cells were seeded in 96-well plates in Ham's F12K medium containing 10\% heatinactivated dialyzed fetal bovine serum (FBS), at a den- 
sity of $0.5 \times 10^{6}$ cells $/ 100 \mu \mathrm{L} /$ well, at $37^{\circ} \mathrm{C}$ for 40 hours. Then, the supernatant was discarded and replaced with medium containing IFN $\gamma(0.4 \mathrm{ng} / \mathrm{ml})$, LPS $(30 \mathrm{ng} / \mathrm{ml})$, (Sigma, St. Louis, Missouri), IL-1 $\beta(5 \mathrm{ng} / \mathrm{ml})$, and TNF $\alpha$ (10 ng/ml) (Pepro Tech Inc., Rocky Hill, New Jersey). Where indicated, cultures were supplemented with either ROL (Shering AG, Berlin, Germany), PTX (Sigma), cilostamide (CIL) (Biomol Research Laboratories, Plymouth Meeting, Pennsylvania), forskolin (Sigma), or cAMP analogs (dibutyryl cAMP or 8-bromo-CAMP) (Sigma). After a further 40 hours of culture, the supernatant was collected for nitrite measurement.

\section{Islet Isolation and Culture}

Mouse islets were isolated from the pancreas of CD-1 mice (5-6 weeks) as previously described (Heitmeier et al, 1997), with Liberase Rl enzyme digestion (Roche Diagnostics, Montreal, Quebec, Canada), according to the manufacturer's instructions. The isolated islets (pooled from 15-18 mice) were isolated on a Ficoll density gradient and cultured overnight in CMRL 1066 medium supplemented with 10\% FBS, soya bean trypsin inhibitors, fungison, and penicillin streptomycin (Gibco, Burlington, Ontario, Canada). Subsequently, the islets were seeded at a density of 400 islets/100 $\mu \mathrm{L} /$ well in 96-well plates in conditioned medium containing IL$1 \beta$, IFN $\gamma$, TNF $\alpha$, and LPS (as described above). After a further 40 hours, the supernatants were collected for nitrite measurement and the plates were frozen at $-80^{\circ} \mathrm{C}$ prior to DNA content measurement.

\section{Determination of Islet Cell Purity}

We trypsinized the isolated islets into single cells using trypsin solution $(0.25 \%$ in PBS). For flow cytometry analysis, the cells were incubated with FITC antimouse CD11b (Mac-1; a macrophage marker) monoclonal antibody (Cedarlane Laboratories, Hornby, Ontario, Canada). To identify macrophages on the basis of phagocytic activity, we incubated the cells with fluorescent microbeads (Cedarlane) for 30 minutes at $37^{\circ} \mathrm{C}$. By fluorescent microscopy, we counted the number of positive cells (three or more fluorescent microbeads inside the cell) in $10 \mu \mathrm{L}$ cell suspension containing $10^{3}$ cells. At least $12 \times 10^{3}$ cells were examined from each islet preparation.

\section{Nitrite Measurement}

Nitrite accumulation as an indicator of NO production was measured using the Griess reagent as we described previously (Prud'homme and Chang, 1999). Absorbance was measured at $540 \mathrm{~nm}$ in a microplate reader (Titertek Instruments, Huntsville, Alabama). Nitrite concentration was calculated from $\mathrm{NaNO}_{2}$ standard curve.

Percent inhibition of nitrite production $=$

$$
100-\frac{\text { (the } \left.\mathrm{NO}_{2}^{-} \text {level with inhibitor }\right) \times 100}{\text { (the } \mathrm{NO}_{2}^{-} \text {level without inhibitor) }}
$$

$I C_{50}$ values were calculated from the dose-response percentage of the inhibition curve for each treatment.

\section{DNA Content Determination by Fluorometric Assay}

We followed the protocol described by Rago et al (1990) with some modifications. Briefly, culture supernatants were removed from the wells containing islet cells or adherent NIT-1 cells (96-well plates). The plates were frozen in $-80^{\circ} \mathrm{C}$ and then thawed until they reached room temperature, and $100 \mu \mathrm{L}$ of TNE buffer (10 mm Tris, $1 \mathrm{~mm}$ EDTA, $2 \mathrm{M} \mathrm{NaCl}$, pH 7.4) was added. The cell lysate was transferred to a microtube with $1 \mathrm{ml}$ of Hoechst (Sigma) 1:2000 dilution of stock solution $(200 \mu \mathrm{g} / \mathrm{ml})$.

The fluorescent emission was measured with a fluorescent spectrophotometer (Hoeffer, San Francisco, California) at a wave length of $457 \mathrm{~nm}$. DNA content was determined from a standard curve obtained with calf thymus DNA (Sigma).

\section{Determination of iNOS mRNA by RT-PCR}

PCR amplification of cDNA with primers specific for iNOS and glyceraldehyde-3-phosphate dehydrogenase (GAPDH) was carried out, and the products were visualized by electrophoresis in $2 \%$ agarose containing ethidium bromide. iNOS primers were as follows: sense, 5'-CTTCCGAAGTTTCTGGCAGCAGCG-3'; antisense, 5'- GAGCCTCGTGGCTTTGGGCTCCTC-3', and the PCR product was $487 \mathrm{bp}$. GAPDH primers were as follows: sense, 5'-TCCACCACCCTGTTGGTGTA-3'; antisense,5'-ACCACAGTCCATGCCATCAC-3', and the PCR product was $450 \mathrm{bp}$. PCR reactions were run for 25 to 35 cycles, and reactions were terminated in the linear portion of the amplification.

\section{Cyclophosphamide-Accelerated Diabetes in NOD}

Female NOD mice (5-6 weeks) were injected ip with cyclophosphamide (CYP) $(250 \mathrm{mg} / \mathrm{kg})$. The mice were treated with either ROL (14 mg/kg), PTX (80 mg/kg), or PBS, ip, bid, for 10 days. The mice were killed, the pancreata were recovered and fixed in 10\% formalin, and histological slides were prepared.

\section{Immunohistochemical Detection of iNOS in the Pancreas}

Immunohistochemistry was performed on formalinfixed tissue with the Histo-Mouse SP kit (Inter Medico, Markham, Ontario, Canada). The primary antibodies were either polyclonal rabbit anti-mouse iNOS (Biomol Research Laboratories) or guinea pig anti-human insulin (which cross-reacts with mouse insulin), followed by biotinylated secondary antibody, streptavidin-peroxidase conjugate, and $A B C$ substrate.

\section{Grading of Insulitis}

Insulitis was graded as described (Prud'homme and Chang, 1999), based on lymphocytic infiltation, as follows: grade 0 , normal islet totally free of any periislet mononuclear cells; grade 1, focal peri-islet infiltrate is less than $25 \%$ of islet circumference; grade 2 , peri-islet infiltrate is greater than $25 \%$ of islet circum- 
ference; grade 3, intra-islet infiltration with good retention of islet cells; and grade 4, extensive intra-islet infiltration with gross distortion or destruction of islet morphology. Coded slides were examined independently by two observers, and statistical analysis was performed with the $\chi^{2}$ test.

\section{Acknowledgements}

Rolipram was a kind of gift of Shering AG (Berlin, Germany).

\section{References}

Andersen HU, Mauricio D, Karlsen AE, Mandrup-Poulsen T, Nielsen JH, and Nerup J (1996). Interleukin-1 beta-induced nitric oxide production from isolated rat islets is modulated by D-glucose and 3-isobutyl-1-methyl xanthine. Eur J Endocrinol 134:251-259.

Badger AM, Olivera DL, and Esser KM (1994). Beneficial effects of phosphodiesterase inhibitors BRL 61063, pentoxifylline, rolipram in murine models of endotoxic shock. Circ Shock 44:188-195.

Belin VD, Mabley JG, James RF, Swift SM, Clayton HA, Titheradge MA, and Green IC (1999). Glucagon decreases cytokine induction of nitric oxide synthase and action on insulin secretion in RIN5F cells and rat and human islets of Langerhans. Cytokine 11:585-592.

Bergmann L, Kroncke KD, Suschek C, and Kolb-Bachofen V (1992). Cytotoxic action of IL-1 $\beta$ against pancreatic islets is mediated via nitric oxide formation and is inhibited by NGmonomethyl-L-arginine. FEBS Lett 299:103-106.

Beshay E, Croze F, and Prud'homme GJ (2001). The phosphodiesterase inhibitors pentoxifylline and rolipram suppress macrophage activation and nitric oxide production in vitro and in vivo. Clin Immunol 98:272-279.

Bielekova B, Lincoln A, McFarland, and Martin R (2000). Therapeutic potential of phosphodiesterase inhibitors in Th1mediated autoimmune diseases. J Immunol 164:1117-1124.

Bulut V, Severn A, and Liew FY (1993). Nitric oxide production by murine macrophage is inhibited by prolonged elevation of cAMP. Biochem Biophys Res Commun 195:11341138.

Cone J, Wang S, Tandon N, Fong M, Sun B, Sakurai K, Yoshitake M, Kambayashi J, and Liu Y (1999). Comparison of the effects of cilostazol and milrinone on intracellular CAMP levels and cellular functions in platelets and cardiac cells. $\mathrm{J}$ Cardiovasc Pharmacol 34:497-504.

Corbett JA, Lancaster JR, Sweetland MA, and McDaniel ML (1991). Interleukin-1 $\beta$-induced formation of EPR-detectable iron-nitrosyl complex in islets of Langerhans. J Biol Chem 266:21351-21354.

Corbett JA and McDaniel ML (1995). Intraislet release of interleukin 1 inhibits $\beta$-cell function by inducing $\beta$-cell expression of inducible nitric oxide synthase. J Exp Med 181:559-568.

Corbett JA, Sweetland MA, Wang JL, Lancaster JR, and Mcdaniel ML (1993). Nitric oxide mediates cytokine-induced inhibition of insulin secretion by human islets of Langerhans. Proc Natl Acad Sci USA 90:1731-1735.

Eizirik DL, Flodstrom M, Karlsen AE, and Welsh N (1996). The harmony of the spheres: Inducible nitric oxide synthase and related genes in pancreatic beta cells. Diabetologia 39:875890.

Flodstrom M, Tyrberg B, Eizirik DL, and Sandler S (1999). Reduced sensitivity of inducible nitric oxide synthasedeficient mice to multiple low-dose streptozotocin-induced diabetes. Diabetes 48:704-713.

Förstermann U and Kleinert H (1995). Nitric oxide synthase: Expression and expressional control of three isoforms. Naunyn Schmiedebergs Arch Pharmacol 352:351-364.

Heitbrock Z, Sternsdrof HWLT, Liese J, Belohradsky B, WeberC, Wedel A, Schreck R, Bäuerle $P$, and Ströbel $M$ (1993). Pyrrolidine-dithiocarbamate inhibits NF- $\kappa \beta$ mobilization and TNF production in human monocytes. $\mathrm{J}$ Immunol 151:6986-6991.

Heitmeier MR, Scarim AL, and Corbett JA (1997). Interferon- $\gamma$ increases the sensitivity of the islets of Langerhans for inducible nitric oxide synthase expression induced by interleukin-1. J Biol Chem 272:13697-13704.

Lauterbach R, Grabowska A, and Marcinkiewicz J (1995). Effect of pentoxifylline on nitric oxide released by murine macrophages. Biol Neonate 67:72-76.

Lee KU, Kim MK, Amano K, Pak CY, Jaworshi MA, Mehta JG, and Yoon JW (1988). Preferential infiltration of macrophages during early stages of insulitis in diabetes-prone BB rats. Diabetes 37:1053-1058.

Liang L, Beshay E, and Prud'homme GJ (1998). The phosphodiesterase inhibitors pentoxifylline and rolipram prevent diabetes in NOD mice. Diabetes 47:570-575.

Liu D, Pavlovic D, Chen MC, Flodstrom M, Sandler S, and Eizirik DL (2000). Cytokines induce apoptosis in beta-cells isolated from mice lacking the inducible isoform of nitric oxide synthase (iNOS -/-). Diabetes 49:1116-1122.

Lowenstein CJ, Dinerman JL, and Snyder SH (1994). Nitric oxide is a physiologic messenger. Ann Intern Med 120:227237.

Mandrup-Poulsen T (1996). The role of interleukin-1 in the pathogenesis of IDDM. Diabetologia 39:1005-1029.

Messmer UK and Brune B (1994). Modulation of inducible nitric oxide synthase in RIN m5F cells. Cell Signal 6:17-24.

Moncada S, Palmer RMJ, and Higgs EA (1991). Nitric oxide: Physiology, pathophysiology, and pharmacology. Pharmacol Rev 43:109-142.

Munzel T, Heitzer T, and Harrison DG (1997). The physiology and pathophysiology of nitric oxide/superoxide system. Herz 22:158-172.

Nussler AK, DiSilvio M, and Billiar TR (1992). Stimulation of the nitric oxide synthase pathway in human hepatocyte by cytokines and endotoxine. J Exp Med 176:261-264.

Pahana K, Namboodiri A, Sheikh F, Smith B, and Singh I (1997). Increased cAMP attenuates induction of inducible nitric oxide synthase in rat primary astrocytes. J Biol Chem 272:7786-7791.

Parker JC, Van Volkenburg MA, Ketchum RJ, Brayman KL, and Andrews KM (1995). Cyclic AMP phosphodiesterase of human and rat islets of Langerhans: Contributions of type III and IV to the modulation of insulin secretion. Biochem Biophys Res Commun 217:916-923.

Prud'homme GJ and Chang Y (1999). Prevetion of autoimmune diabetes by intramuscular gene therapy with a nonviral 
vector encoding an interferon-gamma/lgG1 fusion protein. Gene Ther 6:771-777.

Rabinovitch A and Suarez-Pinzon WL (1998). Cytokines and their roles in pancreatic islet $\beta$-cell destruction and insulindependent diabetes mellitus. Biochem Pharmacol 55:11391149.

Rago R, Michen J, and Wilding G (1990). DNA fluorometric assay in 96 well tissue culture plates using Hoechst 33258 after cell lysis by freezing in distilled water. Anal Biochem 191:31-34.

Rott O, Cash E, and Fleischer B (1993). Phosphodiesterase inhibitor pentoxifylline, a selective suppressor of $\mathrm{T}$ helper type 1- but not type 2-associated lymphokine production, prevents induction of experimental autoimmune encephalomyelitis in Lewis rats. Eur $\mathrm{J} \mathrm{Immunol} \mathrm{23:1745-1751.}$

Schudt C, Tenor H, and Hatzelmann A (1995). PDE isozymes as targets for anti-asthma drugs. Eur Respir J 8:1179-1183.

Schwarz A, Krone C, Trautinger F, Aragane Y, Neuner P, Luger TA, and Schwarz T (1993). Pentoxifylline suppresses irritant and contact hypersensitivity reaction. J Invest Dermatol 101:549-552.
Serreze DV and Leiter EH (1994). Genetic and pathogenic basis of autoimmune diabetes in NOD mice. Curr Opin Immunol 6:900-906.

Sommer N, Loschmann P-A, Northoff GH, Weller M, Steinbach JP, Lichtenfels R, Rietmuller A, and Fontana A (1995). The antidepressant rolipram suppresses cytokine production and prevents autoimmune encephalomyelitis. Nat Med 1:244-248.

Southern C, Schulster D, and Green IC (1990). Inhibition of insulin secretion by interleukin-1 $\beta$ and tumour necrosis factor- $\alpha$ via an L-arginine dependent nitric oxide generation mechanism. FEBS Lett 276:42-44.

Stadler J, Billiar TR, Curran RD, Stuehr DJ, Ochoa JB, and Simmons R (1991). Effect of exogenous and endogenous nitric oxide on mitochondrial respiration of rat hepatocytes. Am J Physiol 260:C910-C916.

Trajkovic V, Badovinac V, Popadic D, Hadzic O, and Stojkovic MM (1997). Cell specific effects of pentoxifylline on nitric oxide production and inducible nitric oxide synthase mRNA expression. Immunology 92:402-406. 